\title{
THE RELATION BETWEEN PROTEIN CONSUMPTION AND DI- URNAL VARIATIONS OF THE ENDOGENOUS CREATININE CLEARANCE IN NORMAL INDIVIDUALS ${ }^{1}$
}

\author{
BY T. ADDIS, ${ }^{2}$ E. BARRETT, L. J. POO, H. J. UREEN, AND R. W. LIPPMAN 3 \\ (From the Department of Medicine, Stanford University School of Medicine, San Francisco, and \\ the Institute for Medical Research, Cedars of Lebanon Hospital, Los Angeles)
}

(Submitted for publication September 11, 1950; accepted, November 13, 1950)

In a previous paper based on the same study (1), it was shown that the serum urea concentration of subjects with intact renal function increases with protein consumption. In contrast, the serum creatinine concentration in such subjects was shown to be independent of protein consumption (2). It has long been known that endogenous urea excretion increases with the protein consumed, while the rate of endogenous creatinine excretion has been shown to be relatively independent of the amount of protein consumed (3).

Popper and Mandel (4) first utilized the endogenous creatinine clearance in man as a measure of the glomerular filtration rate. Steinitz and Türkand (5) found a good correspondence between the inulin and endogenous creatinine clearances in normal subjects. More recently Brod and Sirota (6) have studied the endogenous creatinine chromogen/inulin clearance ratio in man, and concluded that the endogenous creatinine clearance corresponds closely to the inulin clearance in normal subjects. Discrepancies which appear in subjects with renal disease and markedly impaired renal function, are not sufficient to affect seriously the clinical value of the test as a general indicator of renal competence. This judgment has been confirmed by Camara (7), as well as by numerous clinical observations of our own.

Miller and Dubos (8) showed that creatinine is not the only chromogen in human serum that produces color in the Jaffé reaction. The ratio of such "pseudocreatinine" to creatinine is higher in azotemic individuals. Brod and Kotátko (9) found that the endogenous creatinine and the inu-

1 This work, performed in 1945-46, was made possible by a grant from the Nutrition Foundation, Inc.

2 Dr. Addis died June 4, 1949.

${ }^{8}$ Fellow of the John Simon Guggenheim Memorial Foundation. lin clearances approach identity only when the "true" creatinine clearance is used. They used Lloyd's reagent to adsorb creatinine and determined the residual "pseudocreatinine" concentration in the serum.

Diurnal variations in the endogenous creatinine clearance have been studied by Brod (10). He found that the endogenous creatinine clearance in normal individuals is depressed during the night. In a more complete investigation, Sirota, Baldwin and Villarreal (11) studied diurnal variations in renal function of normal male subjects. They found no significant difference in the night and day values for the endogenous creatinine clearance, except for a slight fall in the period from 12 Midnight to 4 A.M. These experiments were conducted on "routine ward" diets, and no attempt was made to vary or to control at a constant level the consumption of protein or of creatininecontaining foods.

Of all renal function tests, the endogenous creatinine clearance is easiest to perform since no foreign substance is infused, the serum concentration is constant, and urine collections can be made over long periods of time, up to 24 hours, thus minimizing the errors in collection. Those who have struggled with the methods for performing inulin determinations realize the relative precision and simplicity of the creatinine determination, as modified by Bonsnes and Taussky (12). For these reasons it seemed desirable to investigate the effect of dietary protein consumption upon the endogenous creatinine clearance and its diurnal variation, since this matter has not been considered in the previous publications.

A clinical test is of optimal usefulness if its performance is simple. For this reason, because we were concerned with the endogenous creatinine clearance as an indicator of renal competence without regard to the possible analysis of indi- 
TABLE I

Diurnal variation of serum creatinine concentration in relation to dietary protein consumption in normal male individuals

\begin{tabular}{|c|c|c|c|c|c|c|c|c|c|c|c|c|}
\hline Diet & \multicolumn{3}{|c|}{ 7:15 A.M. } & \multicolumn{3}{|c|}{ 11:45 A.M. } & \multicolumn{3}{|c|}{ 4:45 P.M. } & \multicolumn{3}{|c|}{ 9:45 P.M. } \\
\hline g. protein/kg. & no. obs. & mg. \% & $\begin{array}{c}\text { stand. dev. } \\
\text { mean }\end{array}$ & no. obs. & mg. \% & $\underset{\text { mean }}{\text { stand. dev. }}$ & no. obs. & mg. \% & $\begin{array}{l}\text { stand. dev. } \\
\text { mean }\end{array}$ & no. obs. & mg. \% & $\begin{array}{c}\text { stand. dev. } \\
\text { mean }\end{array}$ \\
\hline $\begin{array}{l}0.5 \\
1.5 \\
2.5\end{array}$ & $\begin{array}{l}26 \\
18 \\
34\end{array}$ & $\begin{array}{l}1.02 \\
1.00 \\
1.04\end{array}$ & $\begin{array}{l} \pm 0.08 \\
\pm 0.09 \\
\pm 0.07\end{array}$ & $\begin{array}{l}34 \\
18 \\
36\end{array}$ & $\begin{array}{l}1.03 \\
1.01 \\
1.04\end{array}$ & $\begin{array}{l} \pm 0.09 \\
\pm 0.09 \\
\pm 0.07\end{array}$ & $\begin{array}{r}17 \\
8 \\
17\end{array}$ & $\begin{array}{l}1.08 \\
1.05 \\
1.04\end{array}$ & $\begin{array}{l} \pm 0.11 \\
\pm 0.07 \\
\pm 0.07\end{array}$ & $\begin{array}{r}17 \\
9 \\
17\end{array}$ & $\begin{array}{l}1.06 \\
1.09 \\
0.99\end{array}$ & $\begin{array}{l} \pm 0.06 \\
\pm 0.07 \\
\pm 0.09\end{array}$ \\
\hline
\end{tabular}

vidual renal functions, it was not considered desirable to complicate the determinations by the use of Lloyd's reagent. In addition, the test is most useful in evaluating patients with slight degrees of renal functional impairment, before the development of azotemia. In such patients the "pseudocreatinine" chromogen is at a minimum.

\section{METHOD}

\section{Conditions of the experiment}

The conditions have been previously described in detail $(1,2)$. The principal subjects in this study were nine male internes. They were fed carefully contrived diets, all providing more than 2,000 calories per day, with fluid consumption permitted ad libitum. From Monday breakfast (7 A.M.) until Saturday at noon the diet was carefully followed. Over the weekend, until the following Monday at breakfast, the subjects were allowed a free diet. The breakfasts were free of pre-formed creatinine; that is, they contained no meat, fish, or chicken. At other meals meat was used as needed to provide the desired amount of protein. During the first week the diet contained $0.5 \mathrm{~g}$. protein per kg. body weight per day. During the second week the protein content of the diet was $1.5 \mathrm{~g}$. per $\mathrm{kg}$. body weight, and during the third week the protein content was raised to $2.5 \mathrm{~g}$. per $\mathrm{kg}$. body weight. After a gap of two months, the experiment was repeated at lowest and highest levels of protein consumption.

Urine collections and blood specimens were obtained on the last two days of each diet. Friday was divided into four urine collection periods; 7 A.M. to 12 Noon, 12 Noon to 5 P.M., 5 P.M. to 10 P.M. and 10 P.M. to 7 A.M. Blood specimens were obtained just before each meal and at bedtime, with a 15 minute leeway allowed in either direction from the times indicated : $7: 15$ A.M., $11: 45$ A.M., 4:45 P.M. and 9:45 P.M. On Saturday there was a single urine collection from 7 A.M. to 12 Noon, while blood specimens were obtained at 7:15 A.M. and 11:45 A.M.

In order to compare the normal clearance values in women with those in men, a group of 25 female nurses, dietitians and medical students were studied in a similar fashion. However, the experiment was modified for this group and they were studied only on the $0.5 \mathrm{~g}$. protein diet. Urine collections were made each day of the week from 10 P.M. to 7 A.M., while blood specimens were taken daily at $3: 15$ P.M.

\section{Methods of Measurement}

Creatinine determinations were performed by the Folin-Wu method, as modified (2). Clearances were calculated from the measured excretion rate, expressed in mg. per 24 hours, corrected to a body weight of $70 \mathrm{~kg}$. The serum concentration used in the calculation was a logarithmic mean of the concentrations found at the beginning and the end of each period. For body weight corrections, the subjects were weighed daily. Clearance values were corrected by a factor $\frac{70^{0.7}}{\mathrm{BW}^{0.7}}$, where $\mathrm{BW}=$ body weight in kg., in accordance with the suggestion of Addis (13). The calculated clearances were expressed in L. per 24 hours per $70 \mathrm{~kg}$. body weight.

\section{RESULTS}

As has previously been shown (2), the serum creatinine concentration does not vary significantly with diet in normal individuals. From Table $I$ it is seen that the diurnal variation in serum cre-

TABLE II

Diurnal variation of endogenous creatinine excretion in relation to dietary protein consumption in normal male individuals

\begin{tabular}{|c|c|c|c|c|c|c|c|c|c|c|c|c|}
\hline \multirow{2}{*}{ 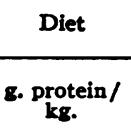 } & \multicolumn{3}{|c|}{7 A.M.-12 Noon } & \multicolumn{3}{|c|}{12 Noon-5 P.M. } & \multicolumn{3}{|c|}{5 P.M.-10 P.M. } & \multicolumn{3}{|c|}{10 P.M.-7 A.M. } \\
\hline & $\begin{array}{l}\text { no. } \\
\text { obs. }\end{array}$ & $\begin{array}{l}\mathrm{mg} . / 24 \mathrm{hrs} . / \\
70 \mathrm{~kg} .\end{array}$ & $\begin{array}{l}\text { stand. } \\
\text { dev. mean }\end{array}$ & $\begin{array}{l}\text { no. } \\
\text { obs. }\end{array}$ & $\begin{array}{l}\mathrm{mg} . / 24 \mathrm{hrs} . / \\
70 \mathrm{~kg} .\end{array}$ & $\begin{array}{l}\text { stand. } \\
\text { dev. mean }\end{array}$ & $\begin{array}{l}\text { no. } \\
\text { obs. }\end{array}$ & $\begin{array}{l}\text { mg. } / 24 \text { hrs./ } \\
70 \mathrm{~kg} .\end{array}$ & $\begin{array}{l}\text { stand. } \\
\text { dev. mean }\end{array}$ & $\begin{array}{l}\text { no. } \\
\text { obs. }\end{array}$ & $\begin{array}{c}\text { mg. } / 24 \text { hrs./ } \\
70 \mathrm{~kg} .\end{array}$ & $\begin{array}{l}\text { stand. } \\
\text { dev. mean }\end{array}$ \\
\hline $\begin{array}{l}0.5 \\
1.5 \\
2.5\end{array}$ & $\begin{array}{l}31 \\
16 \\
33\end{array}$ & $\begin{array}{l}1760 \\
1858 \\
1844\end{array}$ & $\begin{array}{l} \pm 164 \\
\pm 112 \\
\pm 155\end{array}$ & $\begin{array}{r}16 \\
9 \\
14\end{array}$ & $\begin{array}{l}1783 \\
1896 \\
1988\end{array}$ & $\begin{array}{l} \pm 77 \\
\pm 81 \\
\pm 135\end{array}$ & $\begin{array}{r}16 \\
9 \\
18\end{array}$ & $\begin{array}{l}1823 \\
1935 \\
2081\end{array}$ & $\begin{array}{l} \pm 119 \\
\pm 83 \\
\pm 150\end{array}$ & $\begin{array}{r}16 \\
9 \\
17\end{array}$ & $\begin{array}{l}1517 \\
1611 \\
1687\end{array}$ & $\begin{array}{l} \pm 97 \\
\pm 78 \\
\pm 90\end{array}$ \\
\hline
\end{tabular}


TẠBLE III

Diurnal variation of endogenous creatinine clearance in relation to dietary protein consumption in normal male individuals

\begin{tabular}{|c|c|c|c|c|c|c|c|c|c|c|c|c|}
\hline \multirow{2}{*}{ 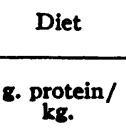 } & \multicolumn{3}{|c|}{7 A.M.-12 Noon } & \multicolumn{3}{|c|}{12 Noon-5 P.M. } & \multicolumn{3}{|c|}{5 P.M.-10 P.M. } & \multicolumn{3}{|c|}{10 P.M. -7 A.M. } \\
\hline & $\begin{array}{l}\text { no. } \\
\text { obs. }\end{array}$ & $\begin{array}{c}\text { L./24 hrs./ } \\
70 \mathrm{~kg} .\end{array}$ & $\begin{array}{l}\text { stand. } \\
\text { dev. mean }\end{array}$ & $\begin{array}{l}\text { no. } \\
\text { obs. }\end{array}$ & $\begin{array}{c}\text { L. } / 24 \mathrm{hrs} . / \\
70 \mathrm{~kg} .\end{array}$ & $\begin{array}{c}\text { stand. } \\
\text { dev. mean }\end{array}$ & $\begin{array}{c}\text { no. } \\
\text { obs. }\end{array}$ & $\begin{array}{c}\text { L. } / 24 \mathrm{hrs} . / \\
70 \mathrm{~kg} .\end{array}$ & $\begin{array}{c}\text { stand. } \\
\text { dev. mean }\end{array}$ & $\begin{array}{l}\text { no. } \\
\text { obs. }\end{array}$ & $\begin{array}{c}\text { L. } / 24 \mathrm{hrs} . / \\
70 \mathrm{~kg} .\end{array}$ & $\begin{array}{l}\text { stand. } \\
\text { dev. mean }\end{array}$ \\
\hline $\begin{array}{l}0.5 \\
1.5 \\
2.5\end{array}$ & $\begin{array}{l}24 \\
16 \\
31\end{array}$ & $\begin{array}{l}171 \\
180 \\
178\end{array}$ & $\begin{array}{l} \pm 17 \\
\pm 17 \\
\pm 17\end{array}$ & $\begin{array}{r}16 \\
8 \\
14\end{array}$ & $\begin{array}{l}167 \\
177 \\
182\end{array}$ & $\begin{array}{l} \pm 15 \\
\pm 10 \\
\pm 17\end{array}$ & $\begin{array}{r}16 \\
8 \\
16\end{array}$ & $\begin{array}{l}166 \\
179 \\
200\end{array}$ & $\begin{array}{l} \pm 15 \\
\pm 14 \\
\pm 14\end{array}$ & $\begin{array}{r}16 \\
9 \\
16\end{array}$ & $\begin{array}{l}141 \\
151 \\
164\end{array}$ & $\begin{array}{l} \pm 12 \\
\pm 15 \\
\pm 13\end{array}$ \\
\hline
\end{tabular}

atinine concentration is insignificant, with a wide range of protein consumption, even though the consumption of pre-formed creatinine was limited to the noon and evening meals.

As seen in Table II, on each diet there is a moderate but significant drop in creatinine excretion during the period from 10 P.M. to 7 A.M. In addition, there is a slight but significant rise in creatinine excretion during all periods, except 7 A.M. to 12 Noon, as the dietary protein consumption rises. Since the serum creatinine concentration remains constant, the clearance values follow the variations in excretion, and this may be seen in Table III.

The female subjects were observed only under one set of conditions, so that effects of diet and diurnal variation were not noted. However, Table IV reveals that both the serum creatinine concentration and the creatinine excretion were lower than the values obtained in males on the same diet and at the same times. In spite of this the mean clearance value was not significantly different from the value obtained in males under similar conditions.

\section{DISCUSSION}

Since there was a drop in creatinine excretion during the period from 10 P.M. to 7 A.M. and there was a rise during the period from 7 A.M. to 12 Noon, after a creatinine-free breakfast, on all diets, the factor responsible for the nocturnal drop

TABLE IV

Nocturnal creatinine clearañce values in normal females on a low protein diet (0.5 g. per kg. per day)

\begin{tabular}{|c|c|c|c|}
\hline & $\begin{array}{l}\text { No. } \\
\text { obs. }\end{array}$ & Value & $\begin{array}{c}\text { Stand. } \\
\text { dev. } \\
\text { mean }\end{array}$ \\
\hline $\begin{array}{l}\text { Serum creat. conc. (3 P.M.) } \\
\text { Creat. excret. (10 P.M.-7 A.M.) }\end{array}$ & $\begin{array}{l}124 \\
124\end{array}$ & $\begin{array}{l}0.79 \mathrm{mg} . \% \\
1147 \mathrm{mg} \cdot / 24 \mathrm{hrs} . / 70\end{array}$ & $\begin{array}{l} \pm 0.07 \\
\pm 94\end{array}$ \\
\hline Creat. clear. (10 P.M.-7 A.M.) & 124 & $146 \mathrm{~L} . / 24 \mathrm{hrs} . / 70 \mathrm{~kg}$. & \pm 14 \\
\hline
\end{tabular}

must be other than the dietary protein consumption. In view of the observations of others that various renal functional measurements rise during recumbency and drop when the erect, lordotic posture is assumed (14-16), it seems improbable that the nocturnal drop in creatinine excretion is a postural effect. Likewise, it seems improbable that this nocturnal drop is the result of diminished physical activity, since several investigators have found that renal functional measurements made at rest are greater than those made during mild exercise and much greater than those made during severe exercise (17-19).

During sleep a much greater degree of relaxation is attained than during rest while awake. There is a generalized relaxation of the vascular bed, manifested by the drop in vascular tension that occurs during sleep in normal individuals. It seems most reasonable to suppose that the nocturnal drop in creatinine excretion, and consequently in the endogenous creatinine clearance, is the result of such a relaxation of the vascular tension, with a drop in filtration pressure at the glomerulus and drop in the glomerular filtration rate. In this connection it is of interest to note that Sirota and his associates (11), by using shorter nocturnal urine collection periods, found the period of diminished inulin and endogenous creatinine clearances to coincide with the period of deepest sleep.

The influence of diet upon the endogenous creatinine clearance is absent in the morning period from 7 A.M. to 12 Noon, after a creatinine-free breakfast. From this it is apparent that the fasting period from supper time until morning is sufficient to obtain basal conditions with respect to creatinine excretion. For this reason, it seems most desirable for clinical determinations to use the morning period for collection, after a creatininefree breakfast. This simply means a normal break- 
fast of eggs, toast, cereal, etc., but without meat or bacon.

In this experiment, there was no significant variation in the serum creatinine concentration of the male subjects under any of the varied conditions, with a grand mean value of $1.03 \mathrm{mg}$. per $100 \mathrm{ml}$. Therefore, it would seem satisfactory to use a serum specimen obtained just before, during, or just after the period of urine collection for calculation of the clearance.

In the female subjects the serum creatinine concentration was slightly, but significantly, lower than in the males, with a mean value of $0.79 \mathrm{mg}$. per $100 \mathrm{ml}$. However, the creatinine excretion was proportionately lower than in the males, so that the mean endogenous creatinine clearance did not differ significantly from the value obtained in males under the same conditions.

The values obtained for the endogenous creatinine clearance during the morning collection period from 7 A.M. to 12 Noon had a mean value of $176 \mathrm{~L}$. per 24 hours per $70 \mathrm{~kg}$. body weight. This is almost identical with the values obtained by Sirota and his colleagues (11) for the "peak," when translated into comparable units.

\section{SUM MARY}

The endogenous creatinine clearance is a valuable, simple, clinical test of renal function. It is affected slightly by the dietary protein consumption and by diurnal variations. These influences may be eliminated, for practical purposes, by collecting urine for the test during the morning after a creatinine-free breakfast. The normal endogenous creatinine clearance under such conditions is $176 \mathrm{~L}$. per 24 hours per $70 \mathrm{~kg}$. body weight, or $122 \mathrm{ml}$. per minute per $70 \mathrm{~kg}$. body weight.

In females the normal mean serum creatinine concentration is $0.79 \mathrm{mg}$. \%, slightly lower than in males. The normal mean endogenous creatinine clearance for female subjects was determined under one set of conditions and did not vary significantly from the values obtained in males.

\section{REFERENCES}

1. Addis, T., Barrett, E., Poo, L. J., and Yuen, D. W., The relation between serum urea concentration and protein consumption of normal individuals. $J$. Clin. Invest., 1947, 26, 869.
2. Barrett, E., and Addis, T., The serum creatinine concentration of normal individuals. J. Clin. Invest., 1947, 26, 875.

3. Folin, O., Laws governing the chemical composition of the urine. Am. J. Physiol., 1905, 13, 66.

4. Popper, H., and Mandel, E., Filtrations- und Resorptions-leistung in der Nierenpathologie. Ergebn. d. inn. Med. u. Kinderh., 1937, 53, 685.

5. Steinitz, K., and Türkand, H., The determination of the glomerular filtration by the endogenous creatinine clearance. J. Clin. Invest., 1940, 19, 285.

6. Brod, J., and Sirota, J. H., The renal clearance of endogenous "creatinine" in man. J. Clin. Invest., 1948, 27, 645.

7. Camara, A. A., Use of the 24-hour endogenous creatinine clearance as a clinical measure of the functional state of the kidneys. J. Clin. Invest., 1950, 29, 802.

8. Miller, B. F., and Dubos, R. J., Determination by a specific enzymatic method of the creatinine content of blood and urine from normal and nephritic individuals. J. Biol. Chem., 1937, 121, 457.

9. Brod, J., and Kotátko, J., Vylučování endogenního kreatininu ledvinami (Clearance of endogenous creatinine by the kidneys). Časop. lék. česk., 1949, 88, 665.

10. Brod, J., Klincský uýznam filtrace a resorpee v ledvinách (Clinical significance of filtration and reabsorption in the kidneys). Časop. lék. česk., 1946, 85, 1915.

11. Sirota, J. H., Baldwin, D. S., and Villarreal, H., Diurnal variations of renal function in man. $\mathrm{J}$. Clin. Invest., 1950, 29, 187.

12. Bonsnes, R. W., and Taussky, H. H., On the colorimetric determination of creatinine by the Jaffé reaction. J. Biol. Chem., 1945, 158, 581.

13. Addis, T., Glomerular Nephritis: Diagnosis and Treatment. The Macmillan Co., New York, 1948, p. 96.

14. Cordero, N., and Friedman, M. H., Influence of posture on phenolsulphonthalein test for kidney function. Arch. Int. Med., 1928, 41, 279.

15. Ni, T. G., and Rehberg, P. B., On the influence of posture on kidney function. J. Physiol., 1931, 71, 331.

16. Bull, G. M., Postural proteinuria. Clin. Sc., 1948, 7, 77.

17. White, H. L., Rosen, I. T., Fisher, S. S., and Wood, G. H., The influence of posture on renal activity. Am. J. Physiol., 1926, 78, 185.

18. White, H. L., and Rolf, D., Effects of exercise and of some other influences on renal circulation in man. Am. J. Physiol., 1948, 152, 505.

19. Chapman, C. B., Henschel, A., Minckler, J., Forsgren, A., and Keys, A., The effect of exercise on renal plasma flow in normal male subjects. J. Clin. Invest., 1948, 27, 639 . 